\title{
Infertility: knowledge and attitudes of Moroccan young people-gender approach
}

\author{
Sana El Adlani ${ }^{1,2,3^{*}}$ D, Abdelhafid Benksim²,3, Yassir Ait Ben Kaddour ${ }^{1}$, Abderraouf Soummani ${ }^{1}$ and \\ Mohamed Cherkaoui ${ }^{2}$
}

\begin{abstract}
Background: The knowledge and the beliefs of people could affect the fertility of women and men all over the society. According to gender, the aim of this study was to describe knowledge level and attitude of Moroccan young people about infertility in Marrakesh-Safi region in Morocco.

Results: We selected 355 Moroccan young people by a simple random sampling method, during 2019 and using a previously validate questionnaire. Both of female and male had a low level knowledge about the meaning, causes, and treatment of infertility (only $20,8 \%$ of female and $25,6 \%$ of male were aware). Almost, half of them (41, $6 \%$ of female versus $51,9 \%$ of male) had reported that it is easier to conceive if the couples had already their first baby. However, $92 \%$ of female and $86 \%$ of male had confirmed that the lifestyle is a factor that may affect the infertility. The results showed that there was a difference between male and female attitude if the fertility treatment fails, the percentage of male who had proposed the polygamy as solution was higher than female (22.5\% versus 6.6\%). Besides, the minority had accepted divorce as alternative. The adoption was another solution proposed and accepted by both male and female.

Conclusion: The result of our study reflects the fact that it is important to investigate on education and a public awareness about fertility in order to upgrade the level of knowledge and attitudes of Moroccan young people.
\end{abstract}

Keywords: Infertility, Knowledge, Attitude, Moroccan young people, Gender

\section{Background}

The fertility is not always controlled by human; there is panoply of factors which influenced fertility, like sociocultural factors; lifestyle; impact of environment on the human body; knowledge of people; social attitudes; and practices $[1,2]$. Thus, the voluntary childlessness is on an increase and can become involuntary childlessness due to fertility diseases [3].

\footnotetext{
* Correspondence: seladlani@gmail.com

${ }^{1}$ Department of Gynecology and Obstetrics, University Hospital Mohammed VI, Marrakech, Morocco

'Laboratory of Human Ecology, Department of Biology, Faculty of Sciences Semlalia, Cadi Ayyad University, Marrakech, Morocco

Full list of author information is available at the end of the article
}

The infertility as a reproductive health disease is defined by the failure to achieve a clinical pregnancy after at least 12 months of regular unprotected sexual intercourse [4]. Generally, 20-35\% of infertility cases due to woman etiology, $20-30 \%$ of cases due to man etiology, $25-40 \%$ of cases due to both of man and woman etiologies and $10 \%$ idiopathic etiology [5].

In Morocco, the infertility is estimated to $15 \%$ of population [6]. Like in developing countries, it is associated to the socially taboo; hence, the man infertility is related to virility and woman infertility is related to dishonor [7]. Consequently, this social perception about infertility can affect fertility behavior. Thus, it is important to act on knowledge and attitude of young people in order to have a favorable behavior toward their fertility 
[8]. According to the theory of Moscovici and Jodlet, the communication, scientific knowledge, and education influenced the social perception, subsequently; the behavior and practices could change toward the health reproductive of people $[9,10]$.

Our study is extended to describe knowledge and attitudes of young Moroccan people, aged between 15 and 25 years old, about infertility to understand the difference in awareness between genders and the importance of education about fertility.

\section{Methods}

We conducted a descriptive study in Marrakesh-Safi region in Morocco. The participants were selected from Marrakesh-Safi region by a simple random sampling method during 2019. The required sample size was estimated 355 participants aged between 15 and 25 years old (male $n^{\prime}=129$; female $n=226$ ). They were questioned about their knowledge and attitude concerning infertility, by administering a semi-structured questionnaire with open and close questions in Arabic language.

The form includes socio-demographic characteristics and questions concerning knowledge and attitude about infertility. Statistical analyses were performed using SPSS package (version 10). The questionnaire was elaborated from a review of literature, and was pretested extensively. The ethical aspects such as self-determination, privacy, anonymity, confidentiality, comfort, and equal treatment were respected.

\section{Results}

Overall, 355 participants were included in this study whose 226 female (average age $M=20.77$ years; SD $=2.2$ ) and 129 male (average age $\mathrm{M}=20.72$ years; $\mathrm{SD}=2.9)$. Most of them had higher school education (Table 1), $88.9 \%$ of female versus $99 \%$ of male $(p=$ 0.001 ). In total, $73.5 \%$ of female versus $60.5 \%$ of male had an urban origin $(p=0.011)$.

The finding of this study affirms that both of female and male had a low level knowledge about the meaning and causes of infertility (20.8\% of female versus $25.6 \%$ of male who had infertility information $(p=0.041))$. Besides, the majority ( $92 \%$ of female and $84.5 \%$ of male) had confirmed that the lifestyle is a factor that may affect the fertility of the couple.

The most of them, $94.7 \%$ of female and $92.2 \%$ of male, had thought that infertility is $100 \%$ curable. Almost, $7.75 \%$ of male and none of female had affirmed that infertility is just a woman problem. The half of participants $(41.6 \%$ of female versus $51.9 \%$ of male) had reported that it is easier to conceive if the couples had already their first baby.
Table 1 Socio-economic and demographic characteristics of participants, distributed by gender

\begin{tabular}{|c|c|c|c|}
\hline Variables and modalities & Female $n=226$ & $\begin{array}{l}\text { Male } \\
n^{\prime}=129\end{array}$ & $P$ value \\
\hline Age of youths (years) & $20.77 \pm 2.2$ & $20.72 \pm 2.9$ & 0.10 \\
\hline \multicolumn{4}{|l|}{ Group age } \\
\hline $15-18$ years & $32(14.2 \%)$ & $30(23.3 \%)$ & 0.030 \\
\hline 18-24 years & $194(85.8 \%)$ & 99 (76.7\%) & \\
\hline \multicolumn{4}{|l|}{ Education level } \\
\hline Primary school & $8(3.5 \%)$ & $13(10.1 \%)$ & \\
\hline College & $17(7.5 \%)$ & $23(17.8 \%)$ & 0.001 \\
\hline High school & $201(88.9 \%)$ & $93(72.1 \%)$ & \\
\hline \multicolumn{4}{|l|}{ Origin } \\
\hline Urban & $166(73.5 \%)$ & $78(60.5 \%)$ & \\
\hline Rural & $60(26.5 \%)$ & $51(39.5 \%)$ & 0.011 \\
\hline \multicolumn{4}{|c|}{ Parental socioeconomic status } \\
\hline Low income & 45 (19.9\%) & $26(20.2 \%)$ & \\
\hline With middle income & $165(73.0 \%)$ & $99(76.7 \%)$ & 0.292 \\
\hline With high income & $16(7.1 \%)$ & $4(3.1 \%)$ & \\
\hline
\end{tabular}

Statistical significance at $p<0.05$

Even the most of the participants thought that infertility is a god's will ( $92 \%$ of female versus $84.5 \%$ of male) (Table 2), just $11.5 \%$ of female and $10.9 \%$ of male had proposed the first resort, if they would be infertile, is prayer (Table 3).

Table 3 shows that the majority had agreed that the first resort is consulting a medical advice $(82.3 \%$ of women versus $79.1 \%$ of men). If the fertility treatment fails, $75.2 \%$ of female and $62.8 \%$ of male had considered the adoption as a solution. But, the percentage of male who had proposed the polygamy was higher than female (22.5\% versus $6.6 \%)$. Just $3.5 \%$ of female versus $3.1 \%$ of male had accepted divorce as alternative.

\section{Discussion}

From the statistical data about socio-economic and demographic characteristics, we notice that the knowledge state of participants was influenced by the following variables: age between 18 and 25 years old, origin (rural or urban) and education level.

\section{Knowledge}

The result shows that the level of knowledge about infertility was considered as low level; thus, fewer than fifty percent of participants $(20.8 \%$ of women and $25.6 \%$ of men) $(p=0.041)$ had gave a definition of the infertility and a low percentage had talked about some causes of it. The majority had affirmed that infertility is $100 \%$ curable. Important proportion of participants had confirmed that the best age for getting pregnant is more than 25 years. 
Table 2 The comparison of basic infertility knowledge, distributed by gender

\begin{tabular}{|c|c|c|c|}
\hline Variables and modalities & $\begin{array}{l}\text { Female }(n=226) \\
\text { Yes/no }\end{array}$ & $\begin{array}{l}\text { Male }\left(n^{\prime}=129\right) \\
\text { Yes/no }\end{array}$ & $P$ value \\
\hline Do you know what infertility is? & $47(20.8 \%)$ & $33(25.6 \%)$ & 0.041 \\
\hline Infertility is a problem for only women? & $0(0.0)$ & $10(7.75)$ & 0.057 \\
\hline If you had a baby once, is it easier to conceive? & $94(41.6 \%)$ & 67 (51.9\%) & 0.063 \\
\hline Infertility is a god's will? & $208(92.0 \%)$ & $109(84.5 \%)$ & 0.027 \\
\hline Infertility is $100 \%$ curable? & $214(94.7 \%)$ & $119(92.2 \%$ & 0.359 \\
\hline Have you ever met an infertile couple? & $138(61.1 \%)$ & $60(46.5 \%)$ & 0.008 \\
\hline Does our lifestyle cause infertility? & $208(92.0 \%)$ & $111(86.0 \%)$ & 0.072 \\
\hline \multicolumn{4}{|l|}{ What is the best age for getting pregnant? } \\
\hline 20 to 24 years & $20(8.8 \%)$ & $14(10.9 \%)$ & 0.672 \\
\hline$\geq 25$ years & $206(91.2 \%)$ & $115(89.1 \%)$ & \\
\hline \multicolumn{4}{|l|}{ Female infertility is caused by? } \\
\hline Genital infections & $795(35.0 \%)$ & $50(38.8 \%)$ & 0.474 \\
\hline Uterine abnormalities & $53(23.5 \%)$ & $21(16.3 \%)$ & 0,110 \\
\hline Hormonal problems & $124(54.9)$ & $62(48.06)$ & 0.400 \\
\hline Menstrual disorders & $77(34.1 \%)$ & $36(27.9 \%)$ & 0.230 \\
\hline Tubal diseases & $78(34.5 \%)$ & $30(23.3 \%)$ & 0.027 \\
\hline \multicolumn{4}{|l|}{ Male infertility is caused by? } \\
\hline Sperm anomalies & $113(50.0 \%)$ & $54(41.9 \%)$ & 0.139 \\
\hline Hormone disorders & $51(22.5 \%)$ & $33(25.5 \%)$ & 0.666 \\
\hline Other diseases & $112(49.6 \%)$ & 67 (51.9\%) & 0.221 \\
\hline
\end{tabular}

Statistical significance at $p<0.05$

Our result corroborate with 71 articles which had presented studies about the knowledge of fertility awareness. Those studies were in different countries of the worlds, Europe, America, and Africa. Among of those studies, the results had showed that the people had a low knowledge and awareness about infertility.
Moreover, the articles had affirmed people through on fertility treatment and they believed that the age could influence the fertility too later [11].

However, both female and male had a higher awareness about the influence of lifestyle on the health reproductive, so $92 \%$ of female and $86 \%$ of male were aware

Table 3 The hypothetical answers regarding possible future infertility, distributed by gender

\begin{tabular}{|c|c|c|c|}
\hline Variables and modalities & $\begin{array}{l}\text { Female }(n=226) \\
\text { Yes/no }\end{array}$ & $\begin{array}{l}\text { Male }\left(n^{\prime}=129\right) \\
\text { Yes/no }\end{array}$ & $P$ value \\
\hline \multicolumn{4}{|l|}{ When the fertility treatment fails? } \\
\hline Would you consider divorce? & $8(3.5 \%)$ & $4(3.1 \%)$ & \\
\hline Would you consider adoption? & $170(75.2 \%)$ & $81(62.8 \%)$ & 0.001 \\
\hline Should you consider remarriage? & $15(6.6 \%)$ & $29(22.5 \%)$ & \\
\hline You do not know? & $33(14.6 \%)$ & $15(11.6 \%)$ & \\
\hline \multicolumn{4}{|c|}{ What is the first resort, if you would be infertile? } \\
\hline Medical advice (hospital) & $186(82.3 \%)$ & $102(79.1 \%)$ & \\
\hline Traditional healer & $2(0.9 \%)$ & $5(3.9 \%)$ & 0.170 \\
\hline Prayer & $26(11.5 \%)$ & $14(10.9 \%)$ & \\
\hline \multicolumn{4}{|l|}{ Treatment options, if you would be infertile? } \\
\hline Should you consider in vitro fertilization? & $59(26.1 \%)$ & $29(22.5 \%)$ & 0.656 \\
\hline Would you consider artificial insemination? & $125(55.4 \%)$ & $74(57.4 \%)$ & 0.706 \\
\hline Should you consider surgery? & $85(37.6 \%)$ & 47 (36.4\%) & 0.825 \\
\hline
\end{tabular}

Statistical significance at $p<0.05$ 
that lifestyle is a risk factor of infertility. Effectively, the environment causes associated to the deterioration of lifestyle (tobacco smoking, alcohol, stress, high temperature, dietary practices, etc.) could affect negatively both of male and female fertility $[12,13]$.

\section{Attitude}

From the result of our study, the majority of interweaved had affirmed that the infertility is a god's will. They had proposed three alternatives, if the treatment failed. The adoption was an alternative proposed by participants ( $75.2 \%$ of women versus $62.8 \%$ of men). In this sense, a lot of studies had confirmed that adoption is the first option of infertile couple if the treatment failed [14]. In the Islamic society, the adoption is completely accepted with specific rules [15].

In the least developed countries, the marriage is related to the procreation; thus, the femininity is associated to the motherhood, also the masculinity and the virility is associated with fatherhood [16]. Additionally, the polygamy is an accepted norm in our society, because Islamic religion gives the opportunity to have more than a wife for man in special conditions [15]. It is why a higher percentage of male had proposed the polygamy as solution (22.5\% male versus $6.6 \%$ female).

Finally, a minority of participants had agreed with the divorce as a solution of infertility if the treatment failed ( $3.5 \%$ female versus $3.1 \%$ male).

\section{Conclusion}

The result of our study reflects the fact that Moroccan young people had a low level of knowledge which often affects their awareness about fertility; their attitudes should influence the behaviors and practices of people about reproductive health. This is why it is important to investigate on education and a public awareness about fertility in order to upgrade the level of knowledge and attitudes of Moroccan young people.

\section{Study limitations}

The study was limited by the characteristic of our population from Marrakesh-Safi region. Thus, in our study, we made comparison just according to gender; it would be important to compare knowledge and attitudes of our study's participants with a young people who had already a medical knowledge. We are increasing this option in the actual research.

\section{Abbreviations}

M: Statistical average age; SD: Sample standard deviation; P: Probability value; $n$ : Sample size of female participants; $n$ : Sample size of male participants

\section{Acknowledgements}

In this study, all authors declare no conflict of interest and no financial support of a company or a financial organization. The authors would like to thank all young people who had participated in this investigation.

\section{Authors' contributions}

SE contributed to conception and design. SE, AB contributed to all experimental work, data and statistical analysis, and interpretation of data. The draft of manuscript was revised by $A B, Y A, A S$, and MC. All authors read and approved the final manuscript.

Funding

Not applicable

Availability of data and materials

In our study, the data and the analysis are available in case a reasonable request is made to the corresponding author.

\section{Declarations}

\section{Ethics approval and consent to participate}

Our research was approved by High Institute of Nursing and Technical Health, Marrakesh, Morocco, and the consent was not obtained from the participants, but we had the authorization from Health authority of Marrakesh. The committee's reference number is not applicable.

\section{Consent for publication}

Not applicable.

\section{Competing interests}

The authors declare that they have no competing interests.

\section{Author details}

${ }^{1}$ Department of Gynecology and Obstetrics, University Hospital Mohammed VI, Marrakech, Morocco. ${ }^{2}$ Laboratory of Human Ecology, Department of Biology, Faculty of Sciences Semlalia, Cadi Ayyad University, Marrakech, Morocco. ${ }^{3}$ High Institute of Nursing and Technical Health, Marrakech, Morocco.

Received: 29 August 2020 Accepted: 18 April 2021 Published online: 03 May 2021

\section{References}

1. Fulford B, Bunting L, Tsibulsky I, Boivin J (2013) The role of knowledge and perceived susceptibility in intentions to optimize fertility: findings from the International Fertility Decision-Making Study (IFDMS). Human Reprod 28(12): 3253-3262. https://doi.org/10.1093/humrep/det373

2. Kumar S, Kumari A, Murarka S (2009) Lifestyle factors in deteriorating male reproductive health. Indian J Exper Biol 47(8):615-624 ISSN: 00195189

3. Fugener J, Matths A, Strauss MB (2013) Knowledge and behaviour of young people concerning fertility risks. Geburtsh Frauenheilk 73(8):800-807. https:// doi.org/10.1055/s-0033-1350761

4. Zegers-Hochschild F, Adamson GD, De Mouzon J, Ishihara O, Mansour R, Nygren K, Sullivan E, Vanderpoel S (2009) International Committee for Monitoring Assisted Reproductive Technology (ICMART) and the World Health Organization (WHO) revised glossary of ART terminology, 2009. Fertility Sterility 92(5):1520-1524. https://doi.org/10.1016/j.fertnstert.2009.09. 009

5. Mustafa M, Sharifa AM, Hadi J, Illzam EM, Aliya S (2019) Male and female infertility: causes, and management. IOSR J Dental Med Sci 18(9):27-32. https://doi.org/10.9790/0853-1809132732

6. Bennani B (2019) 800.000 couples marocains souffrent d'infertilité. Collège Marocain deFertilité. http://college-marocain-fertilite.com/Documentation/ Media/opinion1503.pdf. Accessed 14 Feb 2020

7. Houmenou V, Adjatin A, Tossou MG, Yedomonhan H, Dansi A, Gbenou J, Akoegninou A (2017) Etude ethnobotanique des plantes utilisées dans le traitement de la stérilité féminine dans les départements de l'Ouémé et du plateau au Sud Bénin. Int J Biol Chimical Sci 11(4):1851-1871. https://doi. org/10.4314/ijbcs.v11i4.34

8. Boivin J, Koert E, Harris T, O'shea L, Perryman A, Parker K, Harisson C (2018) An experimental evaluation of the benefits and costs of providing fertility information to adolescents and emerging adults. Human Reprod 33(7): 1247-1253. https://doi.org/10.1093/humrep/dey107

9. Moscovici S (2013) Le scandale de la pensée sociale : Textes inédits sur les représentations sociales réunis et préfacés par Nikos Kalampalikis. Éditions 
de l'École des hautes études en sciences sociales, Paris. https://doi.org/10.4 000/books.editionsehess. 1883

10. Arruda A, Lage E, Madiot B (2008) Une approche engagée en psychologie sociale : I'œeuvre de Denise Jodelet. ERES« Hors collection ». https://doi.org/1 0.3917/eres.madio.2008.01

11. Pedro J, Brandão T, Schmidt L, Costa ME, Martins MV (2018) What do people know about fertility? A systematic review on fertility awareness and its associated factors. UPSALA J Med Sci 123(2):71-81. https://doi.org/10.1 080/03009734.2018.1480186

12. Ilacqu A, Izzo G, Emerenziani GP, Baldari C, Aversa A (2018) Lifestyle and fertility: the influence of stress and quality of life on male fertility. Reprod Biol Endocrinol 16(115):1-11. https://doi.org/10.1186/s12958-018-0436-9

13. Palomba S, Daolio J, Sal R, Battaglia FA, Marci R, La Sala GB (2018) Lifestyle and fertility: the influence of stress and quality of life on female fertility. Reprod Biol Endocrinol 16(113):1-11. https://doi.org/10.1186/s12958-0180434-y

14. Chateauneuf D (2011) Projet familial, infertilité et désir d'enfant : usages et expériences de la procréation médicalement assistée en contexte québécois. Enfances, Familles, Générations. Revue internationale 15:61-77. https://doi.org/10.7202/1008146ar

15. Phaneuf M (2016) Pour des soins interculturels : l'influence des religions, Introduction, pp 1-17 http://www.prendresoin.org/wp-content/uploads/201 6/09/Pour-des-soins_interculturels-2-I-influence-des-religions-Introduction. pdf. Accessed 10 Jul 2020

16. Abolfotouh M, Alabdrabalnabi A, Rehab BA, Umar AA, Samar NH (2013) Knowledge, attitude, and practices of infertility among Saudi couples. Int J Gen Med 6:563-573. https://doi.org/10.2147/IJGM.S46884

\section{Publisher's Note}

Springer Nature remains neutral with regard to jurisdictional claims in published maps and institutional affiliations.

\section{Submit your manuscript to a SpringerOpen ${ }^{\circ}$ journal and benefit from:}

- Convenient online submission

- Rigorous peer review

- Open access: articles freely available online

- High visibility within the field

- Retaining the copyright to your article

Submit your next manuscript at $\boldsymbol{\nabla}$ springeropen.com 